\title{
EVALUATION OF THE SPATIAL DISTRIBUTION OF EVACUATION CENTERS IN METRO MANILA, PHILIPPINES
}

\author{
E. P. Cajucom ${ }^{1,2}$, G. Y. Chao Jr. ${ }^{1,3}$, G. A. Constantino ${ }^{1,4}$, J. A. Ejares ${ }^{1}$, S. J. G. Quillope ${ }^{1,5}$, H. M. Solomon ${ }^{1,6}$, and C. L. Ringor ${ }^{1}$ \\ ${ }^{1}$ Institute of Environmental Science and Meteorology, University of the Philippines Diliman, Quezon City 1101 Philippines - \\ clringor@up.edu.ph; ejaresjay@gmail.com \\ ${ }^{2}$ Department of Science and Technology - Philippine Atmospheric, Geophysical \& Astronomical Services Administration (DOST- \\ PAGASA), BIR Road, Quezon City, 1100 Philippines - cajucom_edward@yahoo.com \\ ${ }^{3}$ University of Santo Tomas - Department of Chemical Engineering, España Boulevard, Sampaloc, Manila 1008 Philippines - \\ gychao@ust.edu.ph \\ ${ }^{4}$ Sultan Kudarat State University, Tacurong City, Sultan Kudarat, 9800 Philippines - gems2shine@ yahoo.com \\ ${ }^{5}$ Department of Agriculture - Agricultural Training Institute, Elliptical Road, Diliman, Quezon City, 1101 Philippines - \\ sjgquillope@gmail.com \\ ${ }^{6}$ Department of Science and Technology - Philippine Nuclear Research Institute (DOST-PNRI), Commonwealth Avenue, Diliman, \\ Quezon City, 1101 Philippines - hmsolomon@pnri.dost.gov.ph
}

KEY WORDS: Evacuation Centers, Metro Manila, Spatial Distribution, Urban, GIS, Disaster Management

\begin{abstract}
:
In a densely populated and hazard-prone megalopolis like Metro Manila, the ability to execute a rapid evacuation protocol is crucial in saving lives and minimizing the damage during disastrous events. However, there is no centralized database on the location of evacuation centers (ECs) in Metro Manila and the available lists are not up-to-date. This study geotagged the current list of ECs in Metro Manila obtained from different government agencies to evaluate the spatial distribution using Geographical Information System (GIS). This is important since the immediate evacuation of residents depends on the proximity and safe location of the ECs. A total of 870 ECs were geo-tagged and validated using the street view of Google Earth ${ }^{\mathrm{TM}}$. EC-to-population ratios were calculated for each of the 16 cities and one municipality of Metro Manila. Values range from $\sim 3,000$ to 81,000 persons per EC. Distance analysis using Thiessen Polygon shows that the ECs are not evenly distributed with proximity areas ranging from 0.0009 to $9.5 \mathrm{~km}^{2}$. Out of the total number of mapped ECs, 392 (45\%) are situated in flood-prone areas while $108(12 \%)$ are within the 1-km buffer hazard zone of an active faultline. Re-evaluation of the locations and the number of ECs per city or municipality is highly recommended to facilitate prompt evacuation when disasters strike.
\end{abstract}

\section{INTRODUCTION}

Natural hazards commonly occur in the Philippines. The most frequent type of hydro-meteorological hazards in the country are tropical storms or typhoons that are accompanied by heavy rain and/or strong winds that may result in floods, landslides and storm surges. The susceptibility of the Philippine archipelago to natural hazards, especially in terms of Tropical Cyclones (TCs), is defined by its geographic location and attributes. An annual average of 19 TCs enter the Philippine Area of Responsibility and nine TCs passed the country based on the 1951 to 2013 data (Cinco et al. 2017). The geology of the country also explains the frequency of earthquakes, tsunamis, and landslides.

Metro Manila, also called the National Capital Region of the Philippines, is the country's center of political, economic, and social activities, resulting in a high volume of domestic migrants (UNESCO, UNDP, IOM, and UN-Habitat). However, the region is exposed to hydrometeorological and geologic hazards. It is transected by an active fault line based on combined historical data and studies by the Philippine Institute of Volcanology and Seismology (PHIVOLCS). The country's National Disaster Risk Reduction and Management Council declared that the West Valley Fault may produce a 7.2 magnitude earthquake with Intensity VIII ground shaking (NDRRMC, 2015). This intensity will cause devastating damage in buildings, landslides, and liquefaction and may result in thousands of casualties (estimated 34,000 deaths) to human lives (JICA-MMDA-PHIVOLCS, 2004). Metro Manila is also perennially plagued with floods. The past flood events indicate that $44 \mathrm{~km}^{2}$ of the land area is floodprone or about $7 \%$ of the $\sim 620 \mathrm{~km}^{2}$. of the megalopolis (Miranda, 1994). However, in September 2009, when tropical storm Ketsana (local name Ondoy) directly crossed over Central Luzon, $\sim 217 \mathrm{~km}^{2}$ (about 34\%) of the metropolis was submerged by floodwaters (Rabonza, 2009). The recurrent floods are the effect of two phenomena: the major floods that have a 2 to 10 -year return period and the isolated flash floods during the monsoon season. The exposure of Metro Manila to such hazards coupled with rapid population growth (1.68\% from 2000-2015), increases vulnerability to disasters.

Pre-impact evacuation of the threatened population is an important management strategy for minimizing potential disastrous events associated with such natural hazards (Perry, 1979). It is crucial to develop a responsive disaster risk reduction and management plan of the region and ensure the availability of established safe evacuation centers (ECs) for emergencies and disasters. A properly implemented evacuation program directly saves lives as well as reduces the loss of property and minimizes disruption of social networks. However, any well-developed emergency response would be futile if EC locations and positioning are not strategically considered relative to disaster risk and if public information on the exact location of ECs is lacking. This study intends to evaluate the susceptibility of ECs to extreme floods and earthquakes. The spatial distribution of the ECs per city or municipality was also examined to determine the proximity area of ECs. In addition, we also calculated the ECs- 
to-population ratio to assess the location-allocation problem in each city or municipality in Metro Manila.

\section{STUDY SITE}

Metro Manila is composed of 16 highly urbanized cities (autonomous local government units that have a minimum population of 200,000 and an annual income of at least USD 100,000 ) and one municipality, encompassing a total land area of $\sim 620 \mathrm{~km}^{2}$. (Figure 1, Table 1). Based on the 2015 census of population, $\sim 12.9 \mathrm{M}$ people reside in the region, equivalent to $\sim 13 \%$ of the country's population. It is the second most populated region in the Philippines and the most densely populated with 20,785 persons $/ \mathrm{km}^{2}$ (PSA, 2015). The United Nations reported that of the world's megacities in 2018, Metro Manila ranked 17th, the largest of the three Southeast Asian megacities, the other two are Jakarta and Bangkok (UN, 2018).

The climate of Metro Manila is divided into two distinct seasons based on rainfall normal values from 1981 to 2010 from three stations: wet from June to October, with rainfall above $200 \mathrm{~mm}$, and dry from November to May. The wettest month is August, with mean rainfall reaching up to $\sim 500 \mathrm{~mm}$. The average annual rainfall totals $\sim 2150 \mathrm{~mm}$. From 1948 to 2018, a total of 18 tropical cyclones have crossed Metro Manila, 11 of which has maximum sustained winds of 120-220 km/h (PAGASA, 2019).

The region is bounded by Manila Bay in the west and Laguna Lake in the southeast (Figure 1). Connecting these two water bodies is the $25 \mathrm{~km}$ long Pasig River, with the main channel flowing through the cities of Manila, Mandaluyong, Makati, Pasig, and Taguig. Northeast of Metro Manila lies the western flank of the Sierra Madre Mountain Range. The presence of this mountain range slows down the movement of a tropical cyclone, allowing more time for rainfall to form (Racoma et al., 2016). In the northwestern coastal area, flooding due to excessive groundwater extraction has been reported (Rodolfo and Siringan, 2006). This area is experiencing land subsidence by several centimeters to more than a decimeter per year, which worsens flooding particularly during storms and high tide events.

An active major fault (Marikina Valley Fault System) transects the eastern portion of Metro Manila for $\sim 135 \mathrm{~km}$ (PHIVOLCS, 1999) (Figure 1). Earthquakes with M6-7 on this fault system is estimated to have recurrence intervals of roughly 400-600 years (Nelson et al., 2000). The soft Quaternary layers with a maximum thickness of $\sim 50 \mathrm{~m}$ covering the coastal area along Manila Bay (Daligdig and Besana, 1993), is expected to amplify high-frequency ground motion (Yamanaka et al., 2011).

\section{METHODOLOGY}

\subsection{Data Collection and Mapping of ECs}

Several lists of evacuation centers were gathered from national government agencies and local government units through correspondence and official requests for information. Some lists were available as downloadable information from official websites. Out of the total 973 identified ECs from the gathered lists, 870 were located on either Google Earth or Google Maps and geotagged for identification of the coordinates. Google Maps' Street View feature helped locate some ECs with missing location details. However, a total of 103 ECs listed were not mapped due to insufficient information regarding the address and location details. Also, a number of identified ECs were identified as duplicate entries on the lists.

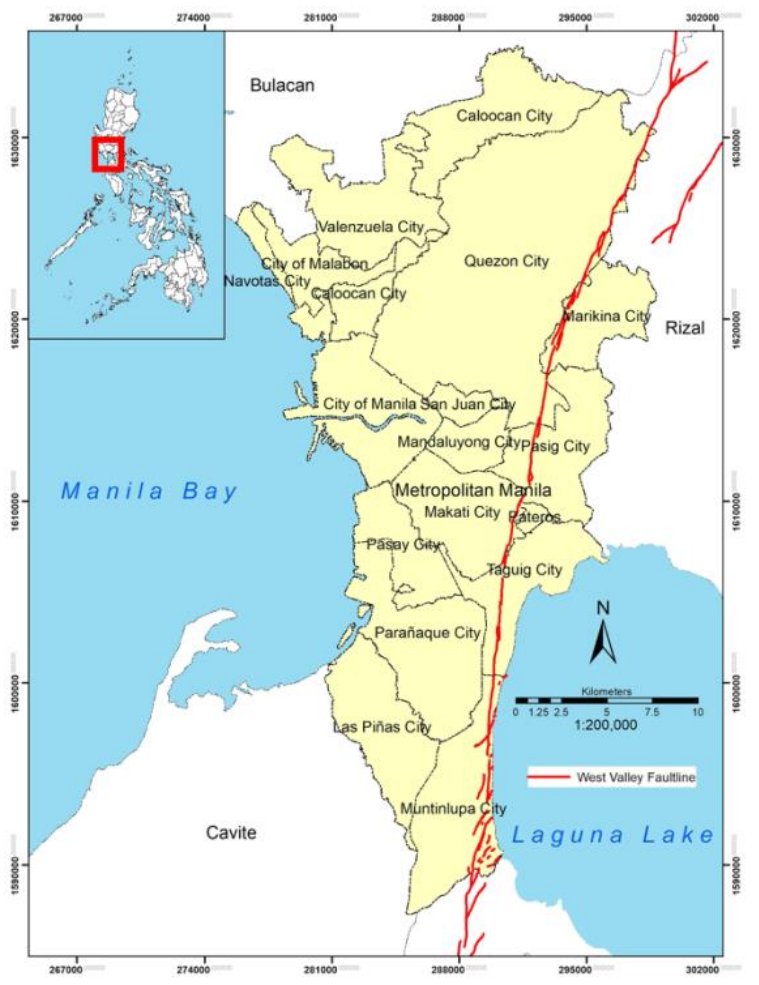

Figure 1. Location of the study area.

GIS hazard maps for flood-prone areas (LiDAR generated) and the West Valley Fault (PHIVOLCS) were extracted and overlaid with the ECs locations using ArcGIS. The flood hazard map (Figure 4) used a 100-year rainfall return period with 10-m resolution obtained from the Department of Science and Technology-University of the Philippines Disaster Risk and Exposure Assessment for Mitigation and Phil-LiDAR Program (https://lipad.dream.upd.edu.ph/, July 16, 2019). Secondary data for population and the land area of the city/municipality were obtained from a 2015 Philippine Statistics Authority census. These were used to calculate the ratios of ECs to both population and land area (Table 1).

\subsection{Spatial Analysis}

The Thiessen Polygon (Voronoi Polygon) apportioned each EC within a city into proximal polygons. Perpendicular bisectors are drawn to the lines joining each measured ECs relative to surrounding ECs. These bisectors formed a series of polygons; each polygon contained one evacuation center. The area of proximity to an EC is identified by calculating the area of each polygon. Any possible location within each polygon is the nearest distance to its given data point (EC) relative to the neighboring ECs. This analysis identified the nearest EC within a neighborhood. The polygons provided information on the ECs proximity (mean, minimum and maximum distance), accessibility and relative distribution (Okabe et al., 2000).

Buffer analysis was used to determine the number of ECs that lie within the 1-km buffer zone of the West Valley Fault. Each EC within the buffer zone was identified as having higher vulnerability in the incidence of fault movement. A 100-year rainfall return flood map was overlaid to the EC points to 
determine the number of ECs that lie within the flood hazard zone.

\section{RESULTS AND DISCUSSION}

\subsection{Spatial Distribution of Evacuation Centers}

The ECs sprawled either sparingly or densely over the whole of Metro Manila (Figure 2). The spatial distribution is influenced primarily by the location of various government-owned facilities. Hence, EC location is not evenly distributed across any of the cities or municipality. Least number of ECs were observed in areas such as forest reserves, exclusive gated communities, commercial centers, and ports. There is an observed absence of ECs in the northeastern part of the study area. It is home to the La Mesa Watershed - a protected area of rainforest which provides potable water to people of Metro Manila. There are smaller segments within Makati, where gated residential communities, high-rise office buildings, and commercial centers are situated, that have very few identified ECs. This pattern is also observable in the neighboring cities of Taguig and Pasig, the surrounding areas near the national penitentiary in Muntinlupa, and the reclaimed areas near the coast, west of Metro Manila.

Table 1. Land area, population, evacuation centers (ECs), and ECs-to-population ratio per city/municipality in Metro Manila. Land area and population data are from the Philippine Statistics Authority (2015).

\begin{tabular}{|c|c|c|c|c|c|c|}
\hline \multirow{2}{*}{\begin{tabular}{|c|} 
City / \\
Municipality
\end{tabular}} & \multirow{2}{*}{\begin{tabular}{|c|} 
Land Area \\
$\left(\mathrm{km}^{2}\right)$
\end{tabular}} & \multirow[t]{2}{*}{ Population } & \multicolumn{2}{|c|}{ ECs } & \multirow{2}{*}{$\begin{array}{c}\text { ECs } \\
\text { Mapped }\end{array}$} & \multirow{2}{*}{$\begin{array}{c}\text { ECs Mapped } \\
\text { Population } \\
\text { Ratio }\end{array}$} \\
\hline & & & Number & Source & & \\
\hline Caloocan & 55.8 & $1,583,978$ & 21 & 1 & 21 & $1: 75,400$ \\
\hline Las Piñas & 32.7 & 588,894 & 70 & 1 & 69 & 1: 8,500 \\
\hline Makati & 21.6 & 582,602 & 106 & 2 & 106 & $1: 5,500$ \\
\hline Malabon & 15.7 & 365,525 & 71 & 2 & 71 & 1: 5,200 \\
\hline Mandaluyong & 9.3 & 386,276 & 34 & 3 & 34 & $1: 11,400$ \\
\hline Manila & 25.0 & $1,780,148$ & 22 & 3 & 22 & $1: 81,000$ \\
\hline Marikina & 21.5 & 450,741 & 17 & 2 & 17 & $1: 26,500$ \\
\hline Muntinlupa & 39.8 & 504,509 & 26 & 3 & 26 & $1: 19,400$ \\
\hline Navotas & 8.9 & 249,463 & 12 & 3 & 12 & $1: 20,800$ \\
\hline Paranaque & 46.6 & 665,822 & 83 & 1 & 83 & $1: 8,000$ \\
\hline Pasay & 14.0 & 416,522 & 18 & 1 & 18 & $1: 23,100$ \\
\hline Pasig & 48.5 & 755,300 & 129 & 1 & 116 & $1: 6,500$ \\
\hline Pateros & 10.4 & 63,840 & 5 & 4 & 5 & $1: 12,800$ \\
\hline Quezon & 171.7 & $2,936,116$ & 242 & 5 & 155 & $1: 19,000$ \\
\hline San Juan & 6.0 & 122,180 & 37 & 1 & 37 & $1: 3,300$ \\
\hline Taguig & 45.2 & 804,915 & 30 & 3 & 28 & $1: 28,700$ \\
\hline Valenzuela & 47.0 & 620,422 & 50 & 3 & 50 & $1: 12,400$ \\
\hline TOTAL & 619.5 & $12,877,253$ & 973 & & 870 & \\
\hline
\end{tabular}

1- Department of Interior and Local Government-Central Office Disaster Information Coordinating Center

2- Department of Social Welfare and Development-Disaster Response Operations Monitoring and Information Center

3 - Department of Interior and Local Government-Central Office Disaster Information Coordinating Center / Department of Social Welfare and Development

4 -Municipal Social Welfare and Development Office of Pateros

5 -Quezon City Disaster Risk Reduction and Management Office

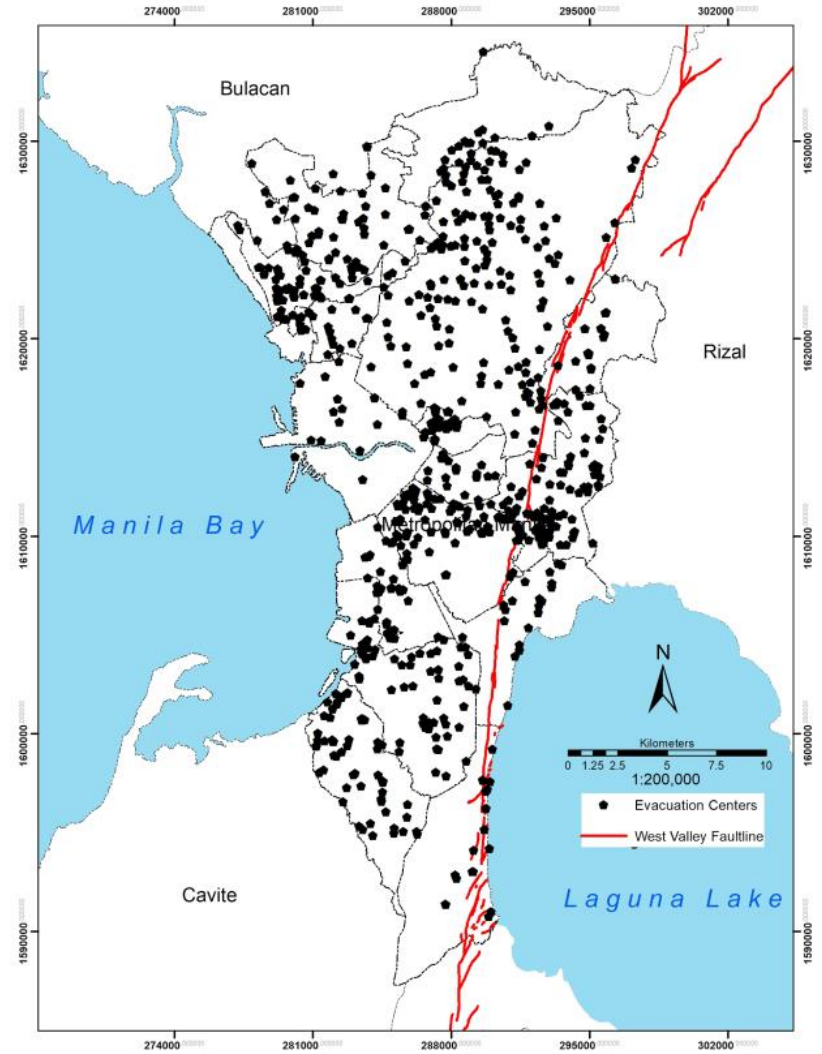

Figure 2. Distribution of evacuation centers in Metro Manila. Table 1 lists the data sources.

The ECs in Metro Manila are structures which are not originally designed to be ECs. These are barangay halls, multipurpose halls, public school buildings, covered basketball courts and public gymnasiums which are converted into evacuation centers when the need arises (Figure 3). Thus, locations of these evacuation centers are not determined by factors concerning disaster risk reduction and management but rather primarily dependent on the location of existing available facilities. The location and proximity of the ECs are important components of an assessment as these dictate the distribution pattern for each city or municipality and the capacity of each evacuation facility.

The linear distances (Euclidean distances) among ECs are fundamental properties to describe their spatial patterns throughout Metro Manila. The mean, minimum, and maximum area of proximity signify the spatial distribution (i.e. uniformly distributed or clumped) and the accessibility of each ECs to the evacuees (Table 2). Distance analysis using Thiessen Polygon shows that the ECs are not evenly distributed with proximity areas ranging from 0.0009 to $9.5 \mathrm{~km}^{2}$. The area of proximity can be used to identify the actual number of constituents that the particular EC will serve by identifying the individual EC jurisdiction. Further, this information helps identify areas that need additional ECs (Boots and Getis, 1988; Masuya et al., 2015).

\subsection{Susceptibility to Flood and Earthquakes}

Out of the total number of mapped ECs, 392 (45\%) are situated in flood-prone areas while $108(12 \%)$ are within the $1-\mathrm{km}$ buffer hazard zone of the active West Valley faultine (Figures $2 \& 4$, Table 3). The cities of Marikina and Pasay were identified as having $>80 \%$ of their ECs within the flood hazard zone. The 
cities of Caloocan, Malabon, Manila and Pasig have $>50 \%$ (but less than $80 \%$ ) of ECs within the flood hazard zone. Navotas is at the bottom of the list with only 1 out of 12 ECs (8.3\%) located in identified flood-prone areas.

All five geotagged ECs of the municipality of Pateros lie within the 1-km buffer zone of the West Valley Fault. Muntinlupa City is also highly vulnerable to earthquakes with $>80 \%$ of its ECs (21 out of 26) within the $1-\mathrm{km}$ buffer zone whereas $20 \%$ to $40 \%$ of ECs in Taguig, Marikina and Pasig fall within the highly vulnerable area. In Quezon City, and in the cities of Paranaque and Makati, $<20 \%$ of ECs fall within the West Valley Fault 1-km buffer zone. ECs outside of the 1-km buffer zone are those located in Caloocan, Las Piñas, Malabon, Mandaluyong, Manila, Navotas, Pasay, San Juan, and Valenzuela.

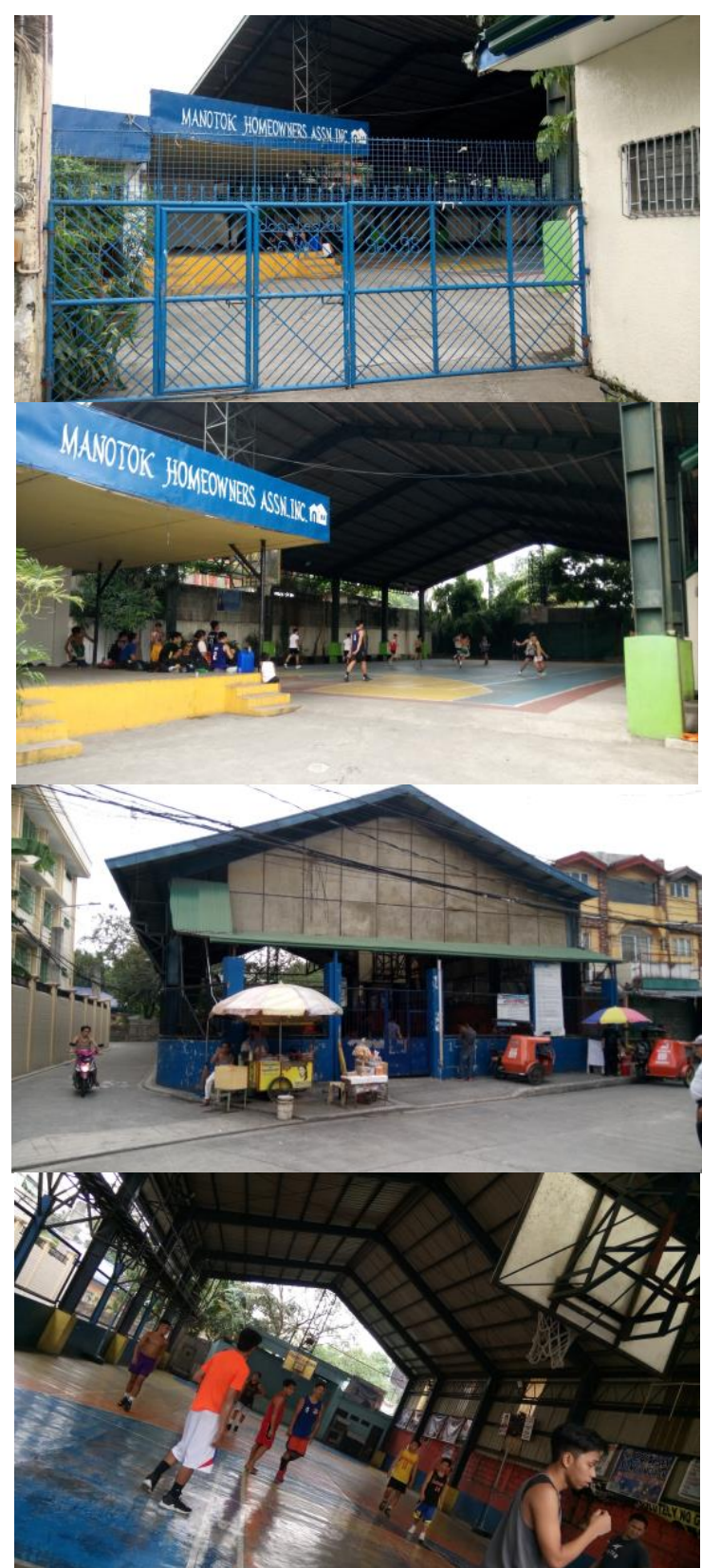

Figure 3. Identified ECs: Manotok Subdivision Covered Court, Marangal Street, Brgy. Baesa, Quezon City (upper two photos); Mendoza Village Covered
Basketball Court, Branches St., Brgy. Sangandaan, Quezon City (bottom two photos).

Table 2. Proximity distance (neighborhood) of evacuation centers in Metro Manila.

\begin{tabular}{|l|c|c|c|c}
\hline \multicolumn{1}{c|}{$\begin{array}{c}\text { City / } \\
\text { Municipality }\end{array}$} & ECs Density & \multicolumn{3}{|c}{ Area of Proximity $\left(\mathbf{k m}^{2}\right)$ of ECs } \\
\cline { 3 - 5 }$\left(\mathbf{p e r} \mathbf{~ k m}^{2}\right)$ & Mean & Min & Max \\
\hline Caloocan & 0.38 & 0.54 & 0.0009 & 2.7 \\
\hline Las Pinas & 2.11 & 1.24 & 0.041 & 8.53 \\
\hline Makati & 4.91 & 0.37 & 0.011 & 3.86 \\
\hline Malabon & 4.52 & 0.25 & 0.007 & 1.03 \\
\hline Mandaluyong & 3.66 & 0.57 & 0.068 & 2.36 \\
\hline Manila & 0.88 & 2.45 & 0.11 & 7.97 \\
\hline Marikina & 0.79 & 1.3 & 0.24 & 6.57 \\
\hline Muntinlupa & 0.65 & 2.14 & 0.058 & 9.5 \\
\hline Navotas & 1.34 & 2.62 & 0.74 & 4.52 \\
\hline Paranaque & 1.78 & 0.67 & 0.073 & 2.75 \\
\hline Pasay & 1.29 & 0.72 & 0.01 & 3.21 \\
\hline Pasig & 2.39 & 0.31 & 0.004 & 1.24 \\
\hline Pateros & 0.48 & 0.24 & 0.09 & 0.38 \\
\hline Quezon & 0.9 & 0.93 & 0.032 & 6.02 \\
\hline San Juan & 6.22 & 0.19 & 0.007 & 2.02 \\
\hline Taguig & 0.62 & 1.38 & 0.097 & 3.86 \\
\hline Valenzuela & 1.06 & 0.81 & 0.009 & 3.33 \\
\hline
\end{tabular}

As a risk reduction measure, evacuation centers which are identified to be susceptible to flood and/or earthquake need to be evaluated in terms of its location. The construction of ECs must also conform to the Philippines' National Building Code, i.e. withstand strong winds $(300 \mathrm{~km} / \mathrm{hr})$ and earthquakes that can register $8.0 \mathrm{M}$ on the Richter scale. Responding to this mandate would require long-term planning and logistics. The strategic decision-making in upgrading the system requires a corresponding resource allocation (Xie et al., 2010). Since extreme natural events in the Philippines often result to calamities, evacuation planning is crucial to prevent loss of lives and minimize damage to properties. The communities should invest in strengthening preparedness measures (Lim et al., 2013). These preparedness measures should have started in 2010 when the Philippine Republic Act No. 10121 mandated local governments to set aside not less than $5 \%$ of their estimated revenue from regular sources for their disaster councils. The allocation should cover the establishment of early warning systems and recovery activities for immediate delivery of food, shelter, and medication. 


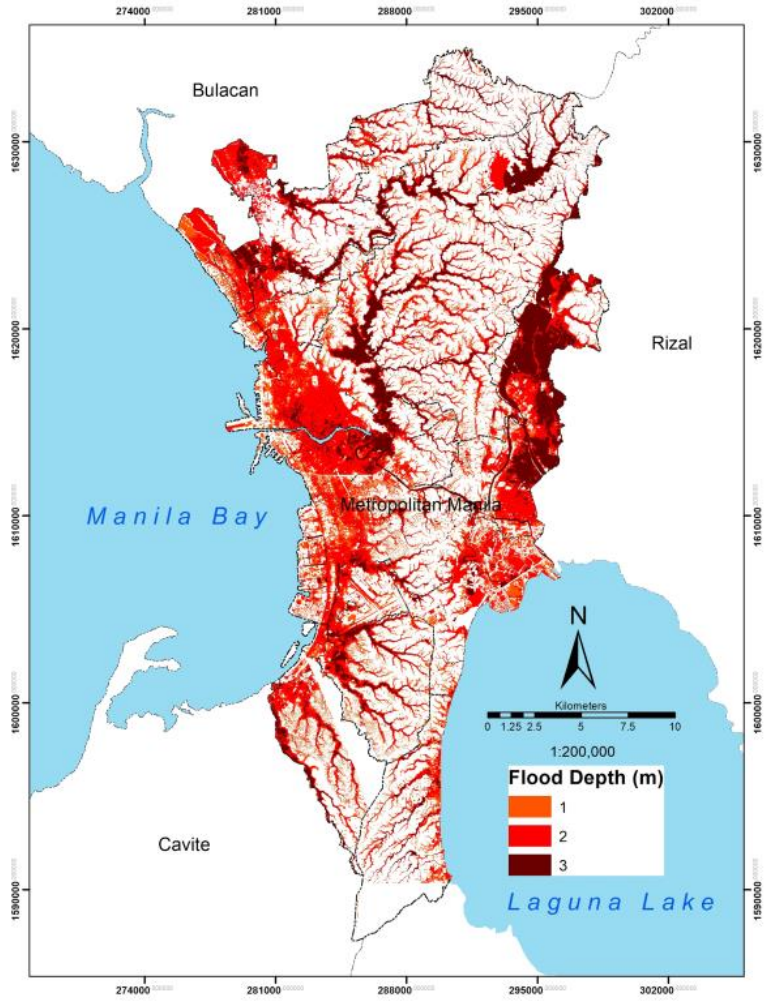

Figure 4. The 100-year return flood hazard map of Metro Manila (Data from LiPAD - LiDAR Portal for Archiving and Distribution).

Table 3. Evacuation centers situated within the flood-prone areas and in the $1 \mathrm{~km}$ buffer of the West Valley Fault.

\begin{tabular}{|c|c|c|c|c|c|}
\hline \begin{tabular}{c|} 
City/ \\
Municipality
\end{tabular} & $\begin{array}{c}\text { Number } \\
\text { of ECs } \\
\text { Mapped }\end{array}$ & $\begin{array}{c}\text { Number } \\
\text { of ECs } \\
\text { Susceptible } \\
\text { to Flood }\end{array}$ & $\begin{array}{c}\text { \% ECs } \\
\text { Susceptible } \\
\text { to Flood }\end{array}$ & $\begin{array}{c}\text { Number of ECs } \\
\text { within } 1 \mathrm{~km} \\
\text { buffer of fault }\end{array}$ & $\begin{array}{c}\% \text { ECs } \\
\text { within the } \\
1 \mathrm{~km} \\
\text { buffer }\end{array}$ \\
\hline Caloocan & 21 & 13 & $61.90 \%$ & 0 & 0 \\
\hline Las Pinas & 69 & 24 & $34.80 \%$ & 0 & 0 \\
\hline Makati & 106 & 45 & $42.50 \%$ & 11 & $10.40 \%$ \\
\hline Malabon & 71 & 43 & $60.60 \%$ & 0 & 0 \\
\hline Mandaluyong & 34 & 9 & $26.50 \%$ & 0 & 0 \\
\hline Manila & 22 & 15 & $68.20 \%$ & 0 & 0 \\
\hline Marikina & 17 & 16 & $94.10 \%$ & 4 & $23.50 \%$ \\
\hline Muntinlupa & 26 & 9 & $34.60 \%$ & 21 & $80.80 \%$ \\
\hline Navotas & 12 & 1 & $8.30 \%$ & 0 & 0 \\
\hline Paranaque & 83 & 35 & $42.20 \%$ & 2 & $2.40 \%$ \\
\hline Pasay & 18 & 16 & $88.90 \%$ & 0 & 0 \\
\hline Pasig & 116 & 68 & $58.60 \%$ & 42 & $36.20 \%$ \\
\hline Pateros & 5 & 2 & $40.00 \%$ & 5 & $100.00 \%$ \\
\hline Quezon & 155 & 63 & $40.60 \%$ & 17 & $11.00 \%$ \\
\hline San Juan & 37 & 13 & $35.10 \%$ & 0 & 0 \\
\hline Taguig & 28 & 9 & $32.10 \%$ & 6 & $21.40 \%$ \\
\hline Valenzuela & 50 & 11 & $22.00 \%$ & 0 & 0 \\
\hline Total & 870 & 392 & $45.10 \%$ & 108 & $12.40 \%$ \\
\hline
\end{tabular}

\subsection{Ratio of Evacuation Center to Population per City/Municipality}

The results identified the City of Manila as having the highest EC-to-population ratio at 1:81,000 followed by Caloocan City $(1: 75,400)$ and Taguig City with 1 EC for every 28,700 people (Table 1). Based on the experience in the aftermath of Typhoon Haiyan, 10 families, with an average of five members per family, overcrowded a standard classroom (Ramos et al., 2015).
Classrooms are common makeshift evacuation facilities and are usually maximized during extreme events. Actual evacuation operations should comply with the recommended ratio of $1: 1.5$ (person to sq.m. floor area) for short-term occupancy and 1:3.5 (person to sq.m. floor area) for the long-term shelter to minimize adverse impact on the health and well-being of the people (Vanuatu Ministry of Climate Change Adaptation, 2016). The problem of congestion in ECs has become a common scenario during evacuation and relief operations in the event of disasters. Insufficient health and sanitation facilities in the designated ECs complicate the problem of congestion and increases the vulnerability of evacuees to post-typhoon diseases.

In the past flood events, as the floods brought about by Typhoon Ketsana in 2009, flood-stricken areas in Metro Manila had to rely on their coping mechanisms and adaptation strategies in response to extreme events (Porio, 2011). This ability is common to groups and individuals exposed to external stresses and disturbances such as typhoons and floods (Adger, 2000) and mostly observed in developing countries (Blaikie et al., 1994).

\subsection{Implication for evacuation strategies by local government units}

4.4.1 Access to information. The country's Freedom of Information Law provides the right of the individual to access any public information. A joint memorandum circular of the national government agencies also states that the identification and listing of ECs as temporary shelters during disasters should be made available to the public including additional information like size, capacity, and susceptibility to hazards. However, a comprehensive list of ECs for Metro Manila is unavailable or missing. Information obtained from official websites and government agencies is in fragments. The acquisition of official documents demands a written request which had to be approved by the head of the corresponding government agency. Whenever information is made available, the location of ECs is described by street names and barangay names and/or numbers. Majority of these ECs have not been geotagged, mapped, nor archived into a standardized list to be made available for public information. With this realization, the accessibility of updated information regarding ECs was the primary problem encountered in this study. This study compiled all gathered information obtained from different government agencies to generate a master list of identified evacuation centers for each city and municipality. The data on the list may be updated regularly. The master list can be used to develop a centralized database for Metro Manila risk reduction and management along with other information and details (e.g. distance, capacity, amenities) of the ECs that can be made accessible online for the consumption of the general public.

4.4.2 Designation of permanent evacuation centers. Even distribution of ECs provides easy access to people in times of disaster (Masuya et al. 2015). The Republic Act 10121 allocates 5\% from local revenue for Local Disaster Risk Reduction Management Fund, of which $30 \%$ is allocated for the Quick Response Fund and $70 \%$ for disaster prevention and mitigation, preparedness, response, rehabilitation and recovery, including the construction of evacuation centers. In the current setup, the spatial distribution of ECs depends primarily on the location and availability of the government facilities that are used as ECs when the need arises. For the ECs to become evenly and strategically distributed throughout Metro Manila, the local governments of these cities and municipality will need to acquire additional properties for the intention of constructing facilities that are dedicated for evacuation operations and disaster 
management. In 2018, the Philippines' Department of Interior and Local Government (DILG) have revised the guidelines in strengthening the evacuation systems. It is now in the hands of the local government units to implement these guidelines.

\section{CONCLUSION}

The goals of establishing a responsive and effective disaster risk reduction and management plan are to save lives and minimize the damage when disasters strike. With the intensification of typhoons occurring in the Philippines and increasing population, evacuation is an essential life-saving measure. Thus, safe and sufficient evacuation centers coupled with an effective evacuation protocol are crucial in achieving these goals. The disaster risk reduction management plan for Metro Manila is at a developing stage with fragments scattered among its 16 component cities and 1 municipality. There is an urgent need for the consolidation of information starting with a comprehensive and up-to-date list of evacuation centers. This study has been able to put together all gathered lists of evacuation centers and geotagged information was added. However, each component list has to be reviewed to include additions and updates. Government policies regarding evacuation centers must be revisited to confirm the existence of the problem of implementation. The spatial analysis of EC distribution in Metro Manila revealed weaknesses particularly on the number of ECs to population ratio for all 17 component study areas. Among the calculated ratios, the best EC-to-population ratio is at 1:3,300 (San Juan City) which still needs a lot of improvement. Proper location of ECs, considering population density of an area and analyzing flood and earthquake susceptibility, not only help solve the problem of congestion but also reduces the risk of loss of lives and damage to property. While most, if not all, of the identified ECs are makeshift shelters which are government buildings or public spaces (i.e. schools, barangay halls, gymnasiums, etc.) by design, it is recommended that future construction and development of additional ECs be based on the DILG guidelines and that location identification be based on spatial distribution and capacity requirements.

\section{ACKNOWLEDGMENTS}

The authors would like to thank the Department of Interior and Local Government-Central Office Disaster Information Coordinating Center, Municipal Social Welfare and Development Office of Pateros, and Quezon City Disaster Risk Reduction and Management Office for its support and assistance in providing the data needed for the completion of this paper.

\section{REFERENCES}

Adger, N.W. 2000. Social and ecological resilience: Are they related? In Progress in Human Geography, 24 (3), 347-364.

Blaikie, P., Cannon, T., Davis, I., and Wisner, B. 1994. At Risk: Natural Hazards, People's Vulnerability and Disasters. London: Routledge.

Boots, B., and A. Getis. 1988. Point Pattern Analysis. Sage University Paper Series on Quantitative Applications in the Social Sciences, series no. 07-001. Sage Publications.

Cinco, T.A., de Guzman, R. G., Ortiz, A.M., Delfino, R.J., Lasco, R., Hilario, F.D., Juanillo, E.L., Barba, R., Ares, E.D. 2016. Observed trends and impacts of tropical cyclones in the
Philippines. International Journal of Climatology, 4638-4650. doi:10.1002/joc.4659.

Daligdig, J.A., and Besana, G.M. 1993. Seismological hazards in Metro Manila: Natural Disaster Prevention and Mitigation in Metropolitan Manila area: Department of Science and Technology, Philippine Institute of Volcanology and Seismology, 9-41.

Department of Education (DepEd)-Department of Social Welfare and Development (DSWD)-Department of Interior and Local Government (DILG)- Department of Health (DOH). 2013. Joint Memorandum Circular (JMC) No. 1. Guidelines on Evacuation Center Coordination and Management. https://www.deped.gov.ph/wp-content/ uploads/2015/06/DM_s2015_058-2.pdf

Department of Interior and Local Government (DILG). 2018. Memorandum Circular No. 122. 2018 - Guidelines for Local Government Units on the Strengthening of Evacuation Systems using the Local Disaster Risk Reduction and Management Fund (LDRRMF)

Japan International Cooperation Agency (JICA), Metropolitan Manila Development Authority (MMDA) and Philippine Institute of Volcanology and Seismology (PHIVOLCS). 2004. Earthquake Impact Reduction Study for Metropolitan Manila (MMEIRS).

https://www.academia.edu/37036504/Earthquake_Impact_Redu ction_Study_Volume_1.PDF

Lim, H.J., Lim, M.B., Piantanakulchai, M.. 2013. A review of recent studies on flood evacuation planning. Journal of Eastern Asia Society for Transportation Studies, 10, 2013.

Masuya, A., Dewan, A., Corner, R. J. 2015. Population evacuation: Evaluating spatial distribution of flood shelters and vulnerable residential units in Dhaka with geographic information systems. Natural Hazards, 78(3), 1859-1882. doi:10.1007/s11069-015-1802-y

Miranda, R. M.1994. Flood control in Metro Manila. In Natural Disaster Mitigation in the Philippines, Proceedings of the National Conference on Natural Disaster Mitigation, 19-21 October 1994, Quezon City, Philippines, Department of Science and Technology-Philippine Institute of Volcanology and Seismology.

National Disaster Risk Reduction and Management Council (NDRRMC). 2015. Metro Manila Earthquake Contingency Plan. http://www.ndrrmc.gov.ph/attachments/ article/1457/vfsintroduction.pdf

National Disaster Risk Reduction and Management Council (NDRRMC). 2011. National Disaster Risk Reduction and Management Plan 2011-2028

Nelson, A., Personius, S.F., Rimando, R.E., Punongbayan, R.S., Tungol, N., Mirabueno, H. 2000. Multiple large earthquakes in the past 1500 years on a fault in Metropolitan Manila, the Philippines. Bulletin of the Seismological Society of America, 90, 73-85

Okabe, A., Boots, B., Sugihara, K., and Chiu, S.N. 2000. Spatial Tessellations: Concepts and Applications of Voronoi Diagrams, 2nd ed. Chichester, UK: John Wiley \& Sons. 
PAGASA. 2019. Philippine Atmospheric Geophysical and Astronomical Services Administration. http://bagong.pagasa.dost.gov.ph/information/climatephilippines

Perry, R. W. 1979. Incentives for Evacuation in Natural Disaster Research Based Community Emergency Planning. Journal of the American Planning Association, 45(4), 440-447. doi:10.1080/01944367908976988

PHIVOLCS.1999. Annual Report of the Philippine Institute of Volcanology and Seismology. Department of Science and Technology, Republic of the Philippines. https://www.phivolcs.dost.gov.ph/

Porio, E. 2011. Vulnerability, Adaptation, and Resilience to Floods and Climate Change-Related Risks among Marginal, Riverine Communities in Metro Manila. Asian Journal of Social Science, 39, 425-445.

https://www.researchgate.net/publication/274342848_Vulnerabi lity_Adaptation_and_Resilience_to_Floods_and_Climate_Chan ge-

Related_Risks_among_Marginal_Riverine_Communities_in_M etro_Manila [accessed May 30 2019].

Philippine Statistics Authority (PSA). 2015. Philippine Population Density (Based on the 2015 Census of Population). Retrieved from https://psa.gov.ph/content/philippinepopulation-density-based-2015-census-population

Ramos, R.A., de los Reyes, V.C., Sucaldito, M.N., Tayag, E. 2015. Rapid health assessments of evacuation centres in areas affected by Typhoon Haiyan. Western Pacific Surveillance and Response Journal, 6(1), 39-43.

doi:10.5365/wpsar.2015.6.2.HYN_003

Rabonza, G. 2009. NDCC Update: Final report on tropical storm "Ondoy" $\{$ Ketsana $\}$ and Typhoon "Pepeng" $\{$ Parma $\}$. National Disaster Coordinating Council. National Disaster Management Center, Camp Gen. Emilio Aguinaldo, Quezon City, Philippines.
Racoma, B. A., David, C. P., Crisologo I. A., Bagtasa, G. 2016. Orographic Effect of Sierra Madre Mountain Range in Luzon, Philippines. Philippine Journal of Science, 145(4), 313-326.

Republic Act No. 10121. 2010. Philippine Disaster Risk Reduction and Management Act of 2010. http://www.ndrrmc.gov.ph/attachments/article/45/Republic_Act _10121.pdf

Rodolfo K.S., Siringan F.P. 2006. Global sea-level rise is recognised, but flooding from anthropogenic land subsidence is ignored around northern Manila Bay, Philippines. Disasters 30(1), 118-39.

United Nations, Department of Economic and Social Affairs, Population Division (2018). World Urbanization Prospects: The $2018 \quad$ Revision. https://www.un.org/ development/desa/publications/2018-revision-of-worldurbanization-prospects.html

Vanuatu Ministry of Climate Change Adaptation, National Disaster Management Office. 2016. Checklist-National Guidelines for the Selection and Assessment of Evacuation Centers. Retrieved May 29, 2019, from https://www.nab.vu/sites/default/files/ documents /Evacuation Centres Guidelines.pdf

Xie, C. Lin, D., Waller, S. 2010. A dynamic evacuation network optimization problem with lane reversal and crossing elimination strategies. Transportation Research Part E: Logistic and Transportation Review, 46(3), 295-313.

Yamanaka, H., Ohtawara, K., Grutas, R., Tiglao, R.B. Lasala, M., Narag, I.C., Bautista, B.C. 2011. Estimation of site amplification and $\mathrm{S}$-wave velocity profiles in metropolitan Manila, the Philippines, from earthquake ground motion records, Exploration Geophysics, 42(1), 69-79, DOI: 10.1071/EG11003 